Proc. Estonian Acad. Sci. Biol. Ecol., 2006, 55, 2, 173-184

\title{
Anatomical features and localization of lignin in needles of Scots pine (Pinus sylvestris L.) on dunes in South-West Estonia
}

\begin{abstract}
Aljona Lukjanova* and Malle Mandre
Department of Ecophysiology, Institute of Forestry and Rural Engineering, Estonian University of Life Sciences, Viljandi mnt. 18B, 11216 Tallinn, Estonia

Received 22 December 2005, in revised form 6 March 2006

Abstract. Anatomical features, including localization of lignin in needles of different age, were studied in Scots pines growing in extreme growth conditions (deficit of water and nutrients in soil) on dunes in South-West Estonia. Analyses showed that the anatomy and level of lignification depend on the location of sampled trees (in the plain, on slopes, or at the top of the dune) and needle age. It was found that the average total cross-section area of needles of the trees growing on the dune decreases with age. Also the areas of xylem, sclerenchyma, and mesophyll are the largest in currentyear needles. Needles of trees growing on the slope of a dune have the greatest proportion of sclerenchyma, xylem, and mesophyll in the total area of the cross-section. Their proportion is the smallest on the top of the dune. Lignification starts already in the current year and first in xylem. The structure of lignin changes over years being more compact in older needles.
\end{abstract}

Key words: Pinus sylvestris, dune, needle anatomy, lignin.

\section{INTRODUCTION}

Lignin, a complex organic polymeric compound, is one of the most important components of the plant cell wall structure and mechanical tissues of vascular plants. Accumulation of lignin in cellular walls causes lignification of cell walls and increases their durability. Lignins impart strength to cell walls, facilitate water transport, and impede the degradation of wall polysaccharides, thus acting as a

*Corresponding author, Aljona.Lukjanova@rmk.ee 
major line of defence against pathogens, insects, and other herbivores (Monties, 1989; Doke et al., 1994; Hatfield \& Vermerris, 2001). The major phase of lignification starts after bud break and is terminated about 4 weeks later (Polle et al., 1994, 1997).

After growth has stopped, intensive accumulation of lignin in cell wall starts, which is accompanied by an increase in the thickness of the cell wall and a decrease in the cell lumen. Often cells loose the protoplast after a secondary cell wall has developed. Such cells continue functioning, fulfilling mainly transfusion and support functions. In accordance with the mechanical function, the structure and chemical composition of the secondary cell wall differ from those of the primary cell wall. The secondary cell wall consists mainly of cellulose or of varying mixtures of cellulose and hemicellulose (Delmer \& Amor, 1995). It may be modified through deposition of lignin (Esau, 1965).

The content of lignin in a lignified cell wall of conifers is about $25-30 \%$ of dry weight (Miidla,1989); this raises cell wall resistance towards deformation (Boudet et al., 1995). Anatomical changes in pine needles have been observed in connection with changes in light conditions and the content of nutrients in the soil (Niinemets et al., 2001). Tissues containing lignin were studied from the same aspect (Lange et al., 1995; Niinemets et al., 2005). The relationship between lignin accumulation and concentration of mineral nutrients in the soil have been of great interest to scientists. For example, the differentiation of young stem tissues is accompanied by a rapid lignin synthesis, especially in the plants grown under nitrogen deficiency, followed by a slow lignin accumulation in older tissues. Secondary metabolism is known to depend on the phase of plant development (Margna, 1990). The plants grown at an increased nitrogen rate contain less lignin (Padu, 1995).

The coastal plain in South-West Estonia has an extensive system of typical dunes. Low coastal dunes covered by pine forest are especially characteristic. Primitive sandy soils with a low concentration of mineral nutrients are typical for dunes (Cramer, 1993; van der Maarel, 1993). The trees on dunes are growing under severe conditions suffering too extensive radiation and insufficient availability of both nutrients and water. The Scots pine is an unassuming species and grows in a fertile as well as in an infertile site. In this area ecophysiological researches concerning needles, wood, and soil have been carried out already since 1985 (Mandre, 2003). The fact that the dunes are unique ecological systems and the presence of a large quantity of interesting data suggested that a more detailed study of needles has to be continued in order to supplement the investigations made earlier. Since lignin is a sufficiently important component in the life of plants, the aim of the present study was to find the changes in the anatomy of needles under the influence of soil fertility and relations between the chemical composition of the soil and lignin accumulation in the cells of needles. 


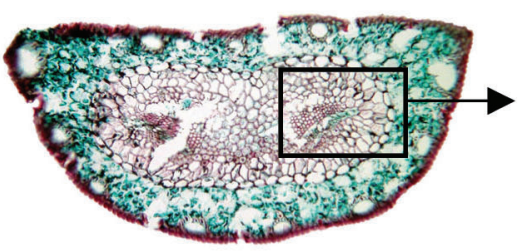

A

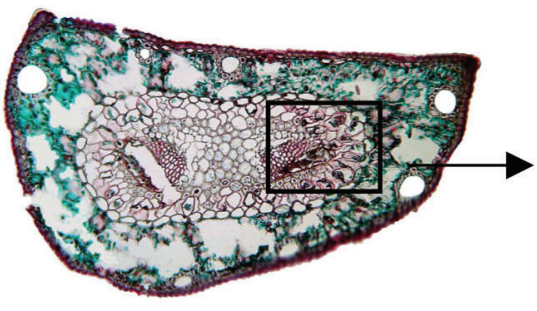

B

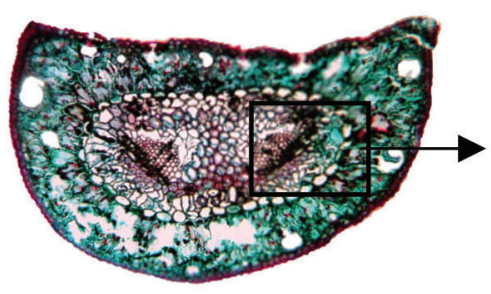

C

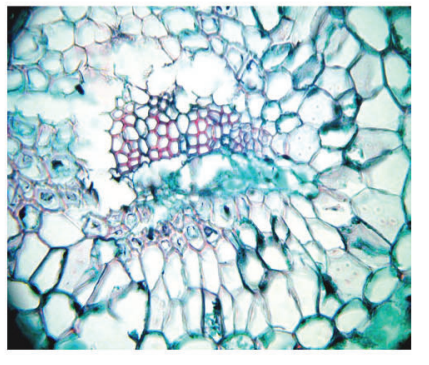

D

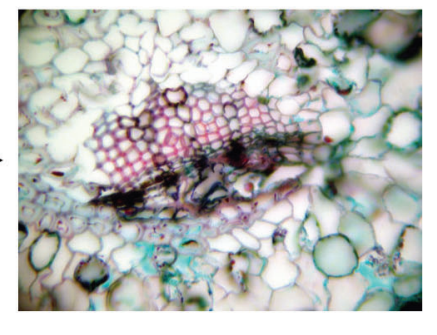

E

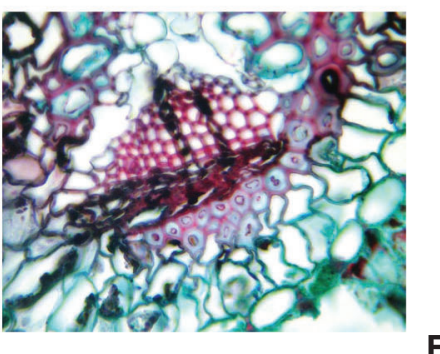

Photo 1. Anatomy of Pinus sylvestris needles of different age on the slope of the dune. General view at $\times 100$ magnification $(A, B, C)$ and vascular bundles at $\times 400$ magnification $(D, E, F)$. Crosssections were stained with safranin and fast green. A - current-year needle and D - vascular bundles of a current-year needle; B - one-year-old needle and E - vascular bundles of a one-year-old needle; $\mathrm{C}$ - two-year-old needle and F - vascular bundles of a two-year-old needle. Stained pink: slightly lignified xylem and sclerenchyma cell walls. Stained red: highly lignified xylem and sclerenchyma cell walls. Increase of intensity of lignification with needle age. 

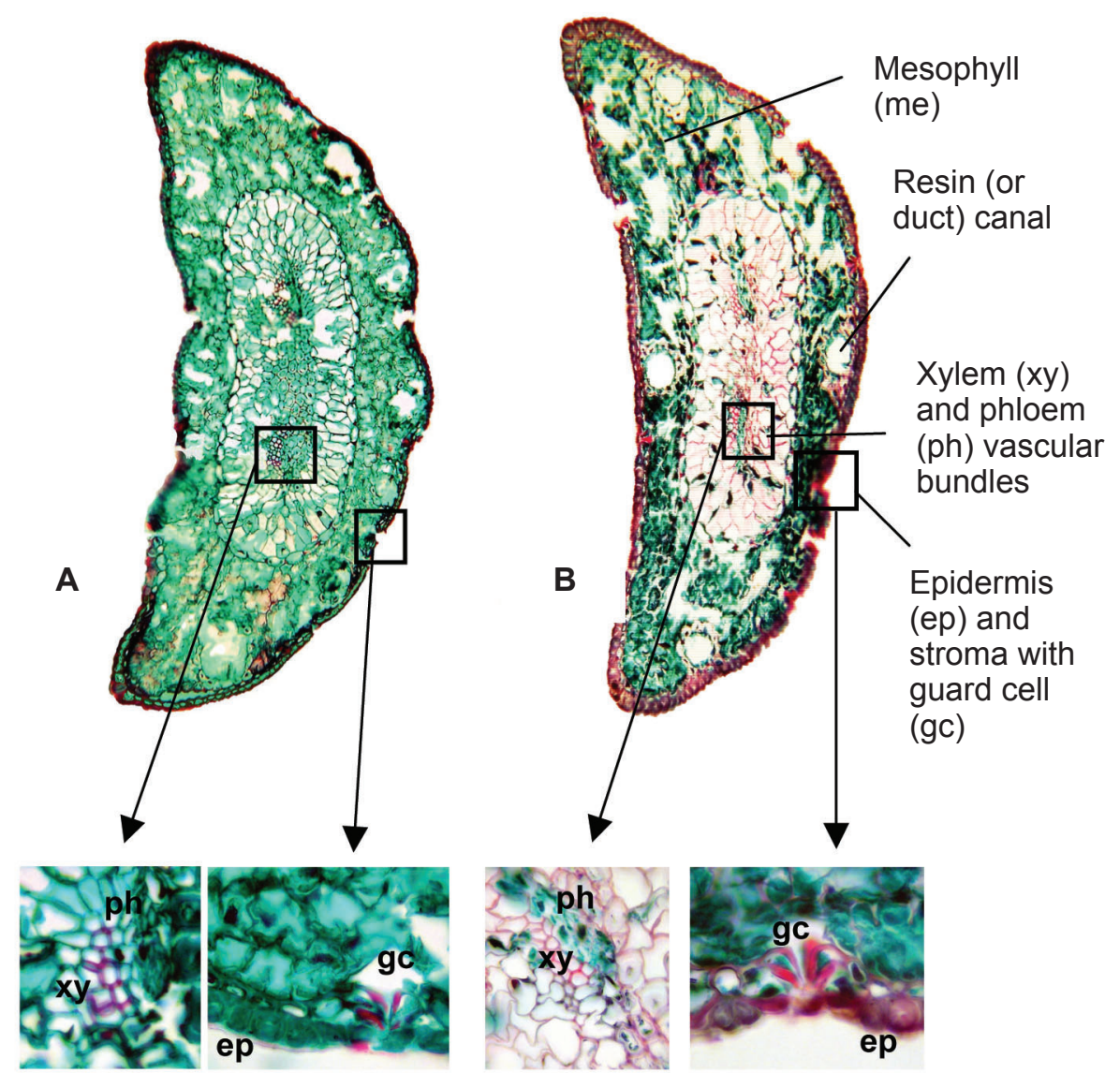

Photo 2. Anatomy of Pinus sylvestris current-year needles viewed at different magnifications. General view of the needle cross-section at $\times 100$ magnification $(A, B)$ and needle tissues at $\times 400$ magnification. Cross-sections (10-15 $\mu \mathrm{m}$ thick) were stained with safranin and fast green. Lignified cell walls were stained red (xylem, sclerenchyma) and other tissues (mesophyll) green. A - needle of a pine growing on the top of the dune, $\mathrm{B}$ - needle of a pine growing on the slope of the dune. Lignified tissues are more intensively stained in the needles of pines growing on the slope of the dune. 


\section{MATERIAL AND METHODS}

\section{Study area and plant material}

The survey was conducted on the dune of Tõotusemägi in South-West Estonia $\left(58^{\circ} 4^{\prime} 59^{\prime \prime} \mathrm{N}, 24^{\circ} 29^{\prime} 39^{\prime \prime} \mathrm{E}\right)$ in 2003 . The transect went along the western foot to the top, and down along the eastern slope. The length of the transect is about $300 \mathrm{~m}$, but the growth conditions of plants are quite different as to relief, chemical composition of soil, water availability, light, and other indicators (Mandre, 2003). The sampled Scots pine (Pinus sylvestris L.) trees grow on the foot, on the western slope, and on the top of the dune (Fig. 1). Current-year, one-year-old, and two-yearold needles were collected from the centre of the crown of each tree for analysis.

\section{Needle anatomy and measurements}

For anatomical analysis cross-sections of needles were made. The needles were pre-fixed with $3 \%$ glutaraldehyde in $0.1 \mathrm{~mol} / \mathrm{L}$ phosphate buffer, $\mathrm{pH} 7.3$, and fixed in $1 \%$ solution of $\mathrm{OsO}_{4}$. Then tissues were dehydrated with ethanol series and embedded in paraffin. Cross-sections of needles $(10-15 \mu \mathrm{m})$ were made with the microtome (Leitz, Germany) and mounted on glass. For lignin visualization, after removing paraffin, the slices were stained with $5 \%$ safranin $\mathrm{O}$ and Fast Green FCF (Fulka, USA). The lignified cell walls were stained red and the others green. The cross-sections were viewed in the bright field at $\times 100$ and $\times 400$ magnification (Micros MC400A, Austria) and photographed with Nikon Coolpix 5400 camera (Nikon, Tokyo, Japan).

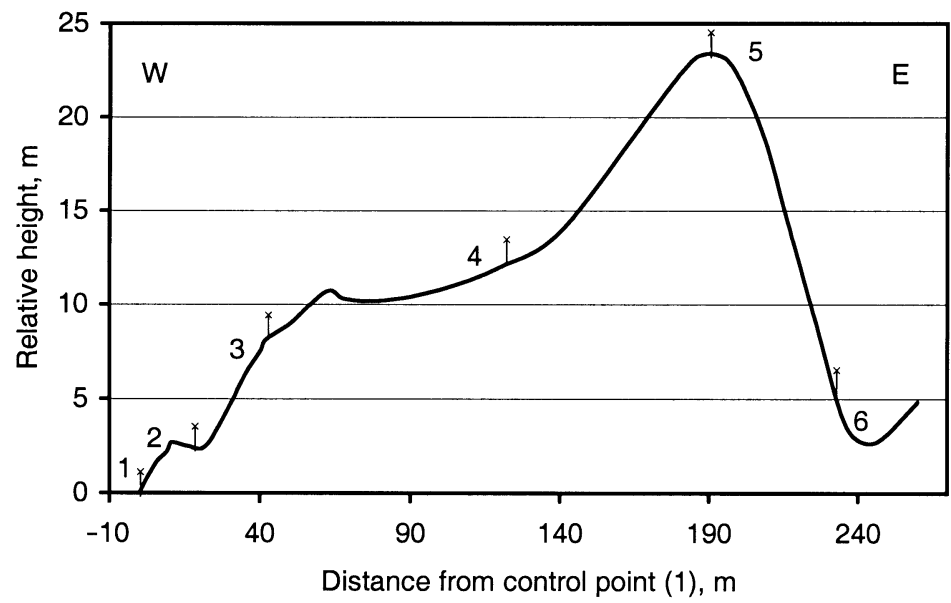

Fig. 1. Sample points on the W-E transect on the dune of Tõotusemägi in South-West Estonia. 1 - sample point on the plain; 2 - slope 1 - sample point on the western slope; 3 -slope 2 - sample point on the western slope; 4 -slope 3 -sample point on the western slope; 5 -top; 6 -slope 4 - sample point on the eastern slope. 
Anatomical peculiarities of needles of different age were analysed. For this purpose the total area, the areas of tissues, and needle width and thickness were measured on the cross-sections in millimetres.

The MapInfo Professional for Windows 4.0 (MapInfo Corp. Inc., Troy, NY) and UTHSCSA Imagetool for Windows Version 3.00 (DT: Don Wilcox, Brent Dove, Doss McDavid, David B Greer, The University of Texas Health Science Center in San Antonio) were used to measure the tissue area from the images (number of measurements was 15). The tissues were separated from epidermis, mesophyll, xylem, phloem, and sclerenchyma. Average values of anatomical characteristics were calculated for all these tissues. The places of lignin localization (tissues stained red) and the amount of lignin by the intensity of staining were analysed visually.

\section{RESULTS AND DISCUSSION}

To identify the lignification process, the tissues accumulating lignin were studied in the needles. Such tissues include sclerenchyma and vascular tissues.

The average values of the parameters measured are presented in Table 1. It can be seen that the average total area of needles decreases with age. The average areas of current-year xylem and epidermis make up $0.8 \%$ and $8.1 \%$ of the area of the total cross-section, respectively. The average areas of the xylem and epidermis of one-year-old needles are $1.1 \%$ and $8 \%$ of the total area. For two-year old needles these parameters are respectively $0.7 \%$ and $8.5 \%$. Taking into account that all tissues in the needles are involved in the lignification process, lignin allocation in current-year needles makes up $4.7 \%$ of the total cross-section area and in the one-year-old and two-year-old needles $5.5 \%$ and $4 \%$, respectively.

It was found that the average total cross-section area of needles is largest in current-year needles. In one-year-old needles the xylem and sclerenchyma make up a larger percentage than in current-year needles but in two-year-old needles their proportion is considerably lower. These data suggest that during the first two years needles have developed the most optimum amount of sclerenchyma and

Table 1. Mean anatomical parameters of needles of Scots pine on the dune of Tõotusemägi in 2004 $(n=15)$

\begin{tabular}{|c|c|c|c|}
\hline \multirow[t]{2}{*}{ Parameter } & \multicolumn{3}{|c|}{ Age of needles } \\
\hline & Current year & 1-yr-old & 2-yr-old \\
\hline Width of needle, mm & 1.20 & 1.13 & 1.25 \\
\hline Thickness of needle, mm & 0.53 & 0.49 & 0.54 \\
\hline Total needle area, $\mathrm{mm}^{2}$ & 319.50 & 294.98 & 244.59 \\
\hline Mesophyll, $\mathrm{mm}^{2}$ & 185.31 & 166.03 & 144.53 \\
\hline Epidermis, $\mathrm{mm}^{2}$ & 25.86 & 23.48 & 20.83 \\
\hline Vascular bundles, $\mathrm{mm}^{2}$ & 3.65 & 5.12 & 3.02 \\
\hline Xylem, $\mathrm{mm}^{2}$ & 2.45 & 3.17 & 1.73 \\
\hline Sclerenchyma, $\mathrm{mm}^{2}$ & 12.56 & 12.95 & 8.13 \\
\hline
\end{tabular}


vascular tissues for efficient transport of mineral nutrients and water to guarantee the needle longevity on the shoot.

Mesophyll average area, measured in $\mathrm{mm}^{2}$, is the largest in current-year needles (Table 1). However, measured in percentage of needle total cross-section area, mesophyll makes up the largest proportion in two-year-old needles $-59.1 \%$. In current-year needles photosynthesis processes and metabolic activity take place to form tissues of needles needed for life. By the end of the second year of development (one-year-old needles) sclerenchyma and vascular tissues are completely formed. In the third year of development the needles (two-year-old needles) are already fully matured, their activity is directed to continuing the processes of photosynthesis, storing reserve substances, and substances needed for the growth of trees.

The anatomical composition of needles varies also depending on the peculiarities of the growth conditions (Niinemets \& Lukjanova, 2003). The conditions for tree growth on coastal dunes are significantly affected by the deficiency of nutrients and water in the soil as well as variation of active radiation (Klõšeiko, 2003; Mandre, 1992, 2003).

In the needles of pines growing on the western slope of the dune of Tõotusemägi the average areas of sclerenchyma and vascular tissues as well as their proportion in the total area of the cross-section fall between the maximum on the foot and the minimum values on the top. The proportion (\%) of the mesophyll in the cross-section area and the average areas of the xylem and sclerenchyma $\left(\mathrm{mm}^{2}\right)$ of the needles on the western slope show maximum values. The smallest levels of these parameters were determined in the pines growing on the top of the dune. However, the proportion of epidermis was high in needles on the top.

The needles on the eastern slope had the largest average values of needle width, length, and total cross-section area compared to pines from the other sample points. The percentage of mesophyll is also the largest in these needles. Analysis of nutrient concentration in the upper soil layers on the selected transect revealed that soils on the plain before the dune and its foot are rather rich in nutrients (Mandre, 1992, 2003). Thus, the widest and the thickest needles with the largest total cross-section area grow on pines in nutrient-rich soil. The needles of pines in the western plain had the highest concentration of mineral elements and needles on the eastern slope had the greatest dry mass (Mandre, 1992, 2003). Soil analysis revealed decreasing concentrations of most nutrients from the slope towards the top, only the concentration of P increases (Mandre, 2003) (Fig. 2). At the same time the availability of water to trees falls and the soil temperature rises. To these factors the increasing drying effect of the sun and wind towards the top is added. The pines growing on the top of the dune have difficulties in obtaining minerals and water, which affects their anatomical parameters. Small supply of mineral nutrients through the vascular tissues, the wind, and relatively strong radiation brought about the intensive development of the proportion of sclerenchyma and epidermis to increase the tolerance of needles in extreme growth conditions. Figure 3 shows the distribution of tissues of pine needles of different age on the different sample points on the dune. 


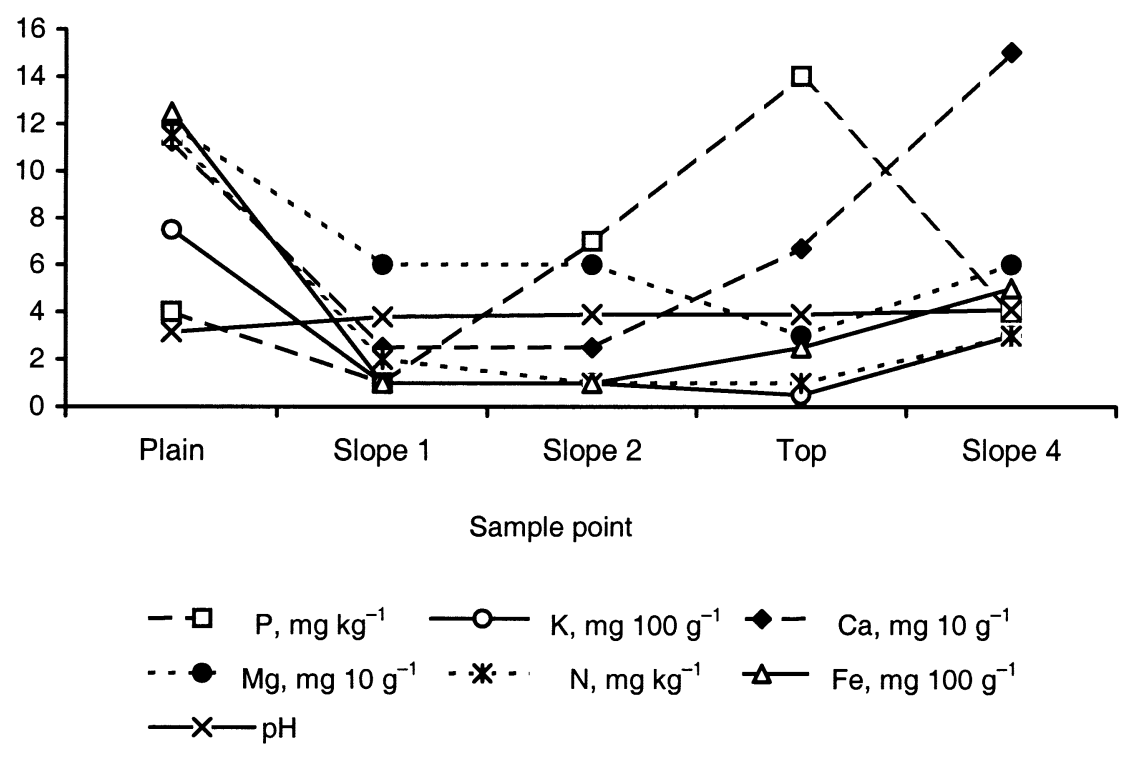

Fig. 2. Concentration of mineral elements and the $\mathrm{pH}$ of the soil samples on the $\mathrm{W}-\mathrm{E}$ transect on the dune of Tõotusemägi in South-West Estonia. cr.yr. - current-year needles, 1-yr. - one-year-old needles, 2-yr. - two-year-old needles.

Visual analysis of the cross-section showed that lignin accumulation starts already in the vascular tissues of current-year needles, especially in the cell wall of the xylem. Anatomy studies of Norway spruce needles led to the same conclusions (Polle et al., 1994).

Later epidermis and thereafter sclerenchyma cells become involved in lignification. In the current-year needles xylem cellular walls, stomata guard cells, and the cuticle stained partially or totally red after histochemical reaction showing lignin accumulation. The epidermis was also stained, but only external cellular walls covered with the cuticle turned red. The colour intensified in the preparations of one-year-old and two-year-old needles. In some samples also the sclerenchyma, the mechanical tissue that carries a supportive function, was stained (Photo 1).

To sum up, we can say that the lignification process taking place in the needles can be followed in mechanical and vascular tissues. The areas of tissues accumulating lignin increase mainly during the two first years, but the intensity of the colour is the highest in the two-year-old needles, where lignin structure becomes denser and accumulation more compact. The obtained results agree with the data of the studies carried out with spruce needles by Hanisch \& Kilz (1990).

The site located on the top of the dune and the uppermost site on the slope are relatively similar as to their edaphic and radiation conditions. Therefore the anatomical parameters of the needles and the character of lignification are rather similar in these sites. This study established that in the pines growing in the uppermost site on the slope lignin was visible only in current-year and one-year-old 

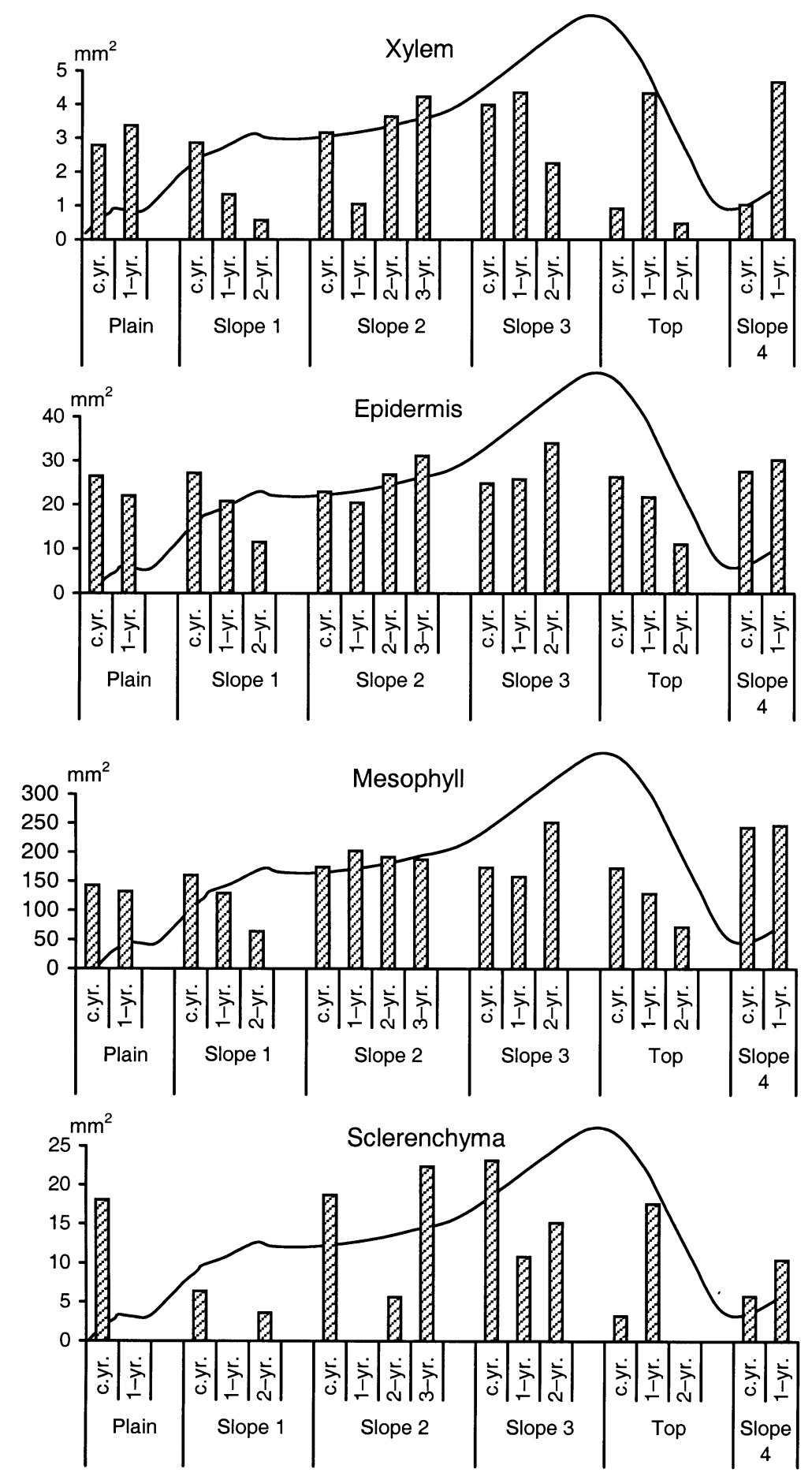

Fig. 3. Dependence of the distribution of tissues in Scots pine needles on needle age and location of sample plot on the dune on the Tõotusemägi transect. 
needles whereas in the needles on the top lignin was not intensively stained either in older or younger needles. As a rule, lignification induces programmed death of the cells involved (Ziegler, 1997). Therefore, it can be assumed that the one- and two-year old needles from the top of the dune should look anatomically (physiologically) younger than the needles of the same age of trees growing on slopes. Nonintensive lignification of these needles supports our opinion. In unfavourable conditions the already formed and well functioning needles were preserved longer on the tree to avoid expenditures for generating new needles.

The average dry mass of the needles on the top is comparable to that on the slope, but the total amount of mineral nutrients is smaller (Mandre, 2003), also the mesophyll, the tissue responsible for photosynthesis, as well as the areas of mechanical and vascular tissues where lignin is stored are smaller on the top. It allows us to conclude that the small amount of lignin found in these samples is due to the difficulties in assimilating nutrients in the extreme growth conditions.

Photo 2 shows the differences in the accumulation of lignin in mechanical and vascular tissues in the current-year needles of Scots pines growing on the slope and on the top of the dune of Tõotusemägi.

\section{CONCLUSIONS}

The study revealed the dependence of the variation in the anatomical parameters and lignification process in the needles of Scots pines growing on dunes in South-West Estonia on the age of needles and the location of sample points on the dune. It was found that Scots pine needles of different age differed in their distribution of tissues and anatomical parameters. The youngest, current-year needles had the largest cross-section area.

Lignification starts already in the current year in the cell walls of the xylem of the vascular bundle. As known, the mineral nutrients move via the vascular bundle (Glavac \& Tesche, 1997) and therefore primary lignin storage occurs in the cell walls of these tissues. Mechanical tissues with thick walls become involved in the lignification process later. The structure of lignin changes over years, and accumulation becomes more compact in older needles. This can also be followed in Photo 1 of the analysed needles by the changing intensity of the red colour.

A relationship between the lignification of needles and the character of growth conditions on the dune was established. In general the soils of dunes do not contain sufficient amounts of nutrients for optimum growth of Scots pine. The trees growing on the slope of the dune in soils relatively richer in nutrients showed a more intensive lignification process than the trees growing on the top of the dune, in which practically no lignin storage was observed using histochemical methods. This can be explained by unfavourable growth conditions - shortage of water, poor availability of mineral nutrients, too intensive radiation. The lignification process of Scots pines growing on dunes needs more detailed investigations on anatomical, histochemical, as well as biochemical levels. 


\section{ACKNOWLEDGEMENTS}

This research was supported by the Estonian Ministry of Education and Research (project No. 0432153s02) and the Estonian Science Foundation (grant No. 6022).

\section{REFERENCES}

Boudet, A. M., Lapierre, C. \& Grima-Pettenati, J. 1995. Biochemistry and molecular biology of lignification. New Phytol., 129, 203-236.

Cramer, W. 1993. Dry coastal ecosystems of the northern Baltic Sea. In Ecosystems of the World 2A. Dry Coastal Ecosystems. Polar Regions and Europe (van der Maarel, E., ed.), pp. 95-108. Elsevier, Amsterdam.

Delmer, D. P. \& Amor, Y. 1995. Cellulose biosynthesis. Plant Cell, 7, 967-1000.

Doke, N., Miura, Y., Sanchez, L. M. \& Kawakita, K. 1994. Involvement of superoxide radical in signal transduction: responses to attack by pathogens, physical and chemical shocks, and UV-radiation. In Causes of Phytooxidative Stress and Amelioration of Defense Systems in Plants (Foyer, C. H. \& Mullineaux, P., eds), pp. 177-197. CRC Press, Boca Raton.

Esau, K. 1965. Plant Anatomy. John Wiley and Sons, New York.

Glavac, V. \& Tesche, M. 1997. Xylem transport and mineral mobilization. In Trees - Contributions to Modern Tree Physiology (Rennenberg, H., Eschrich, W. \& Ziegler, H., eds), pp. 165-175. Backhuys Publishers, Leiden.

Hanisch, B. \& Kilz, E. 1990. Monitoring of Forest Damage. Spruce and Pine. Christopher Helm, London.

Hatfield, R. \& Vermerris, W. 2001. Lignin formation in plant. The dilemma of linkage specificity. Plant Physiol., 126, 1351-1357.

Klõšeiko, J. 2003. Relationship between the light environment and carbohydrates in needles of Scots pine (Pinus sylvestris) on a dune. Metsanduslikud uurimused, 39, 50-57.

Lange, B. M., Lapierre, C. \& Sandermann, H. 1995. Elicitor-spruce (Picea abies (L.) Karst.) stress lignin: structural similarity to early developmental lignins. Plant Physiol., 108, 1277-1287.

Mandre, M. 1992. A comparative analysis of the nutrient content in Scots pine (Pinus sylvestris) on a dune and in a bog in South-West Estonia. In Estonia. Man and Nature, pp. 54-76. Academy of Sciences of Estonia, Tallinn.

Mandre, M. 2003. Conditions for mineral nutrition and content of nutrients in Scots pine (Pinus sylvestris) on dunes in Southwest Estonia. Metsanduslikud uurimused, 39, 32-42.

Margna, U. 1990. Relationship Between Biosynthesis of Flavonoides and Primary Metabolism of Plants. VINITI, Moskva (in Russian).

Miidla, H. 1989. Biochemistry of lignin formation. In The Formation of Lignin in Wheat Plants and Its Connection with Mineral Nutrition. Publications in Plant Physiology and Plant Biochemistry, 5. Acta Comm. Univ. Tartu., 845. Tartu, 11-23.

Monties, B. 1989. Lignins. In Methods in Plant Biochemistry (Dey, P. M. \& Harborne, J. B., series eds). Plant Phenolics. Vol. 1 (Harborne, J. B., ed.), pp. 113-157. Academic Press, London.

Niinemets, Ü. \& Lukjanova, A. 2003. Needle longevity, shoot growth and branching frequency in relation to site fertility and within-canopy light conditions in Pinus sylvestris. Ann. For. Sci., 60, 196-208.

Niinemets, Ü., Ellsworth, D. S., Lukjanova, A. \& Tobias, M. 2001. Site fertility and the morphological and photosynthetic acclimation of Pinus sylvestris needles to light. Tree Physiol., 21, 12311244.

Niinemets, Ü., Lukjanova, A., Sparrow, A. D. \& Turnbull, M. H. 2005. Light-acclimation of cladode photosynthetic potentials in Casuarina glauca: trade-offs between physiological and structural investments. Funct. Plant Biol., 32, 571-582. 
Padu, E. Kh. 1995. Properties of peroxidases and phenylalanine ammonia-lyase in wheat stems during secondary cell wall formation and lignificaion. Russ. J. Plant Physl., 42, 358-365.

Polle, A., Otter, T. \& Seifert, F. 1994. Apoplastic peroxidases and lignification in needles of Norway spruce (Picea abies L.). Plant Physiol., 106, 53-60.

Polle, A., Otter, T. \& Sandermann, J. 1997. Biochemistry and physiology of lignin synthesis. In Trees - Contributions to Modern Tree Physiology (Rennenberg, H., Eschrich, W. \& Ziegler, H., eds), pp. 455-475. Backhuys Publishers, Leiden.

van der Maarel, E. 1993. Geographical and ecological types of dry coastal ecosystems. In Ecosystems of the World 2A. Dry Coastal Ecosystems. Polar Regions and Europe (van der Maarel, E., ed.), pp. 7-14. Elsevier, Amsterdam.

Ziegler, H. 1997. Some open questions in tree physiology. In Trees - Contributions to Modern Tree Physiology (Rennenberg, H., Eschrich, W. \& Ziegler, H., eds), pp. 531-544. Backhuys Publishers, Leiden.

\title{
Edela-Eesti luidetel kasvavate mändide (Pinus sylvestris) okaste anatoomilised iseärasused ja lignifikatsioon
}

\author{
Aljona Lukjanova ja Malle Mandre
}

Männiokaste anatoomilist ehitust ja ligniini lokalisatsiooni uuriti Edela-Eesti luitestiku tüüpilisel luitel Tõotusemäel (58 $4^{\prime} 59^{\prime \prime}$ N, 2429'39" E) 2003. a. Luite tipus on kujunenud puude kasvuks ekstreemsed tingimused ja toitainete ning vee defitsiit on olulisemateks puude füsioloogilist seisundit mõjutavateks teguriteks. On selgunud, et okaste anatoomia ja lignifikatsioon on oluliselt sõltuv puude kasvukohast luitel ja okaste vanusest. Luite tipus kasvavate mändidega võrreldes on luite nõlval kasvavate puude okastel täheldatud tunduvalt suuremat ksüleemi, sklerenhüümi ja mesofülli osa üldises okka ristlõikes. Samas on ksüleemi, sklerenhüümi ja mesofülli osa okaste ristlõikes suurim noorimates, jooksva aasta okastes. Kuigi okaste lignifikatsioon algab juba jooksva aasta okastes, muutub ligniini struktuur kompaktseks mändide vanemates, kaheaastastes okastes. Luite tipus vee ja toitainete defitsiidi tingimustes kasvavate mändide okaste lignifikatsioon on vähem intensiivne kui luite nõlvadel ja jalamil kasvavatel mändidel. 